\title{
Çocuklarda COVID-19 Enfeksiyonunun Tanısı, Tedavisi ve Korunma Yolları
}

\author{
Diagnosis, Treatment and Prevention Methods of Pediatric COVID-19 Infection
}

\section{凶ا̈̈ner Özdemir'1, (DAyşegül Pala²}

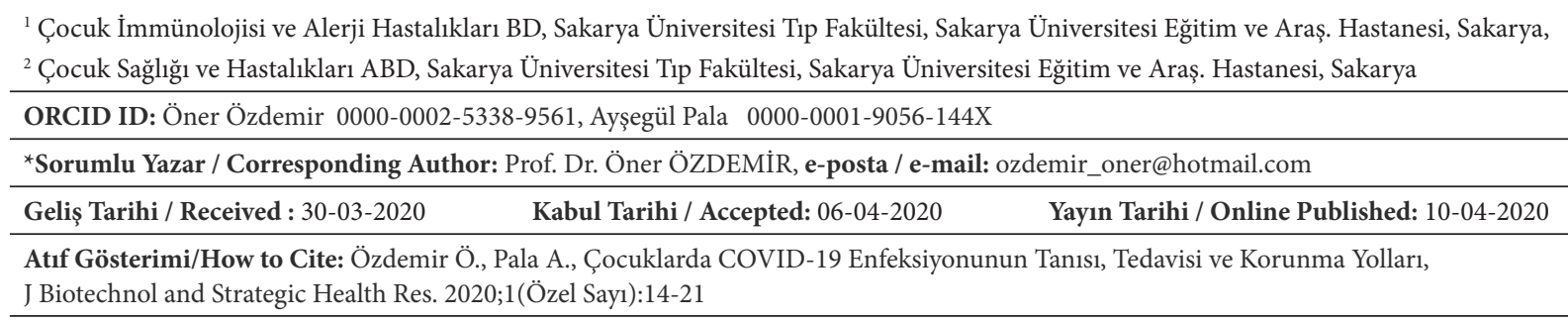

Öz

Koronavirüsler (KoV), tek-zincirli RNA virüsleri olup alfa, beta, gamma ve delta olmak üzere dört gruba ayrılır. İnsanlarda genelde solunum ve gastrointestinal sistemde hastalıklara neden olurlar. Koronavirüsler çok hızlı mutasyon geçirdiklerinden dolayı yeni KoV tipleri ortaya çıar ve hayvanlardan bulaşarak insanlarda hastalık yapabilir. 2002 yılında Çin’de ağır akut solunum sendromu koronavirüsü (SARS-KoV) ve 2012 yılında Suudi Arabistan'da Orta Doğu solunum sendromu koronavirüsü (MERS$\mathrm{KoV}$ ) olarak iki yeni koronavirüs ortaya çıktı. 2019 sonunda, yine Çin’de yeni bir koronavirüs (SARS-KoV-2) küresel bir salgın hastalığına (COVID-2019) neden oldu. İlk bulgulara göre SARS-KoV-2 çocuklarda asemptomatik veya hafif semptomlara neden olduğu gösterilmiştir. Erişkinlerde klinik tablo soğuk algınlığından bronşit, pnömoni, ağır akut solunum sıkıntısı sendromu (ARDS) ve ölümle sonuçlanan çoklu-organ yetmezliğine kadar değişebilir. Çocukların virüsün yayılmasındaki rolü tam olarak bilinmemektedir. Bu derlemede, çocuk hastalardaki yeni KoV enfeksiyonunun (COVID-19) klinik ve tanısal bulgularını, tedavisini ve önleme yollarını anlatmayı hedefledik.

Anahtar SARS-KoV-2, çocuk, ateş.

Kelimeler

\begin{abstract}
Coronaviruses (CoVs) are single-stranded RNA viruses classified into four genera: alpha, beta, gamma and delta. They often cause respiratory and gastrointestinal tract diseases in human. As coronaviruses rapidly evolve by new mutations, new types of CoVs emerge and cause disease through transmission from animals to humans. Two novel CoVs [severe acute respiratory syndrome coronavirus (SARS-CoV)] in China in 2002 and Middle East respiratory syndrome coronavirus (MERS-CoV) in Saudi Arabia in 2012, have emerged. At the end of 2019, a new coronavirus (SARS-CoV-2) in China caused a disease (called as) and global outbreak. Based on the first reports, SARS-CoV-2 has been shown to cause asymptomatic or mild symptoms in children. In adults, the clinical presentation can range from common cold to bronchitis, pneumonia, severe acute respiratory distress syndrome (ARDS), and multi organ failure even resulting in death. The role of children in the transmission of the virus is not fully known. In this review, we aim to discuss the clinical and diagnostic findings, treatment and prevention methods of the new CoV infection (COVID-19) in pediatric patients.
\end{abstract}

Keywords SARS-CoV-2, children, fever. 


\section{GIIRIŞ}

Koronavirüsler $(\mathrm{KoV})$, Coronaviridae ailesine ait olup zarflı, 40-60 nm boyutlarında, tek-zincirli zoonotik RNA virüsleridir. ${ }^{1}$ Koronavirüslerin alt gruplarından alfa- ve beta-koronavirüs daha çok memelileri enfekte ederken, gamma- ve delta-koronavirüsler ise kuşları enfekte eder. Koronavirüs hayvanlarda solunum, gastrointestinal, kardiyovasküler sistemleri etkilerken, insanlarda ise çoğunlukla solunum ve gastrointestinal sistem hastalıklarına neden olur. ${ }^{2}$ Klinik tabloda soğuk algınlığı olabileceği gibi bronşit, pnömoni, ağır akut solunum sıkıntısı sendromu (ARDS), koagülasyon bozuklukları ve ölümle sonuçlanan çoklu-organ yetmezliği gelişebilmektedir. Koronavirüsler oldukça hızlı mutasyon ve rekombinasyon yeteneğine sahip olduklarında yeni $\mathrm{KoV}$ tipleri ortaya çıkar ve hayvanlardan insanlara yayıldığında hastalık yapabilirler. ${ }^{3}$ Örneğin, yeni KoV olarak 2002 yılında Çin'de yarasalardan bulaşan ağır akut solunum sendromu koronavirüsü (SARS-KoV) ve 2012 yilında Suudi Arabistan'da develerden insana bulaşan Orta Doğu solunum sendromu koronavrüsü (MERS-KoV) türleri ortaya çıktı. ${ }^{4}$ Insanları enfekte eden koronavirüslerin alt tipleri HCoV-229E, HCoV-OC43, HCoV-NL63 ve HKU1-CoV'dir. ${ }^{5}$

Günümüz itibari ile halen etkisini sürdüren yeni KoV 2019 Aralık ayında Çin'in Wuhan kentinde ortaya çıktı ve buna SARS-KoV-2 adı verildi. SARS-KoV-2'nin betakoronavirüs sınıfına ait SARS ile \%87-89 nükleotit benzerliği olan bir virüs olduğu gözlendi. ${ }^{6}$ SARS-KoV-2 enfeksiyonu ilk olarak Çin'in Hubei eyaleti Wuhan şehrinde bazı yetişkinlerde görülen etiyolojisi belirsiz pnömoni vakaları ile başladı. Daha sonra virüsün semptomatik ve asemptomatik enfekte insanlardan diğer insanlara damlacık veya temas yoluyla geçebilmesi ile birlikte ilerleyen günlerde Wuhan şehrinde başlayan SARS-KoV-2 dünya geneline yayılarak küresel bir pandemi haline geldi. ${ }^{7}$ SARS-KoV-2'nin neden olduğu bu klinik hastalığa ise COVID-19 adı verildi. ${ }^{8}$ Derlememizde, çocuk hastalardaki yeni KoV (COVID-19) enfeksiyonunun klinik ve tanısal bulgularını, tedavisini ve önleme yollarını anlatmayı hedefledik.

\section{Epidemiyoloji}

SARS-KoV-2 enfeksiyonu ilk olarak Çin'deki yerel bir deniz ürünleri satan markette çalışan ve orayı ziyaret eden kişilerde görüldü. Daha sonra kişiden kişiye temasın ana yayılım yolu olduğu gözlendi. ${ }^{9} \mathrm{Bu}$ enfeksiyonun tüm yaş gruplarında görülebildiği ve hapşırma/öksürme sonrasında saçılan damlacıklar yoluyla bulaştığı gözlendi. Damlacıkla yaklaşık iki metreden fazla uzaklıkta bulaşamaz ve havada çok asılı kalamaz. Uygun hava koşullarında SARSKov-2 yüzeylerde yaşayabilir ancak sodyum hidroklorür, hidrojen peroksit gibi dezenfektanlarla temizlenebilir. Enfeksiyon, kişiden kişiye damlacık inhalasyonu veya virüsle-kontamine yerlere dokunma sonrası göz, burun ve ağız teması ile bulaşır. ${ }^{10}$ Ocak 2020-Şubat 2020 tarihleri arasında Çin'deki COVID-19 enfeksiyonu tespit edilen 2.143 çocuğun yaşları 1-18 arasında olup medyan yaş 7 ve hastaların \%57'si erkek hastalardan oluşuyordu. Bu çocuklardan sadece \%4'ü asemptomatik iken \%90'u hafif veya orta şiddette semptomlara sahipti. Geri kalanların \%5'inde ağır tablo (oksijen satürasyonu: <\%92) mevcut ve sadece 33 'ünde akut solunum sıkıntısı sendromu ve solunum yetmezliği olup kritik hastaydı. Ağır/kritik hasta insidansının \%11 oranı ile 1 yaş altı çocuklarda en yüksek olduğu gözlendi. ${ }^{11}$

\section{Özel durumlar \\ Hamile kadınlar}

Gebelikte COVID-19 ile alakalı bilgiler oldukça azdır ancak günümüze kadar intrauterin veya vertikal bir yayılım görülmemiştir. Yenidoğanlarda da enfeksiyon bildirilmiştir. Bildirilen iki enfeksiyon vakasından ilki anne temasından kaynaklanmış ve 17. günde tanısı konulmuş iken; ikinci vaka için yeterli veri yoktur. COVID-19 şüphesi olan gebe kadının tanı, tedavi, önlem ve yaklaşımı diğer gebe olmayan kadınlarla benzerdir. Bu annelerin çocukları izole edilmeli ve uygun şekilde değerlendirilmelidir. ${ }^{12,13}$

\section{Emzirme}

Emzirmenin virüs yayılımına neden olup olmadığı bilinmemektedir ancak emzirme esnasinda damlacık yoluyla bebeğe bulaşması mümkün olabilir. COVID-19 enfekte 
anneler veya semptomlarını gösteren şüpheli annelerin emzirme esnasında el hijyeni ve yüz maskesi kullanımına dikkat etmelerinde fayda vardır. ${ }^{14}$

\section{Yenidoğanlar}

Ocak 2020- Şubat 2020 tarihleri arasında COVID-19 enfeksiyonu kesin tanılı 9 anne ve 10 yenidoğan (biri ikiz) üzerinde yapılan değerlendirmede, 4 annenin doğumdan önce, 2 annenin doğum esnasında, 3 annenin de doğum sonrası enfekte olduğu raporlanmıştır. Annelerde en sık görülen semptomlar ateş ve öksürüktü. Bu annelerin çocuklarının 6’sında klinik olarak nefes darlığı, ikisinde ateş, ikisinde karaciğer fonksiyon testlerinde bozukluk ve trombositopeni, birinde hızlı kalp atımı, birinde kusma ve sonuncusunda pnömotoraks izlendi. Yenidoğanlardan 5 tanesi iyileşirken, 4 tanesinin durumu hastanede stabil seyrederken 1'i exitus oldu. Ancak 9 çocukta doğum sonrası yapılan SARS-Kov-2 testi negatif çıktı. SARS-Kov-2 perinatal enfeksiyonları yenidoğan üzerinde fetal sıkıntıdan erken doğum, solunum sıkıntısı, trombositopeni, karaciğer fonksiyon testlerinde bozukluklara hatta ölüme bile neden olabilir. ${ }^{13}$

26 Mart 2020 tarihinde JAMA dergisinden çıkan güncel bir vaka raporunda virüse-özgü IgM antikorlarının yenidoğan serolojik örneklerinde görüldüğü ve bu serolojik parametrelerin tanıda kullanabileceğini ve vertikal bir geçişe işaret edebileceği iddia edilmiştir. ${ }^{15}$

\section{Klinik bulguları}

COVID-19 hastalığının kuluçka süresi 1 ila 14 gün arasinda olmakla beraber, ortalama 5-6 gündür. Şu ana kadar bildirilen çalışmalarda, çocuklarda görülme yaş sınırı 1,5 ay-17 yaş arasındadır. Bu çocukların da ya ailesindeki bireylerden ya da hasta kişilerden enfekte olduğu görülmüştür. ${ }^{16}$ Çocuklarda asemptomatik seyredebileceği gibi semptomatik vakalarda ateş, kuru öksürük, yorgunluk, baş ağrısına rastlanır. ${ }^{1,6,17}$ Bazı vakalarda burun tıkanıklığı, burun akıntısı, mide bulantısı, kusma ve ishal semptomları görülebilir. Çocuklar çoğunlukla hastalığı hafif semptom- larla geçirirken, ateş veya pnömoni varlığ leştirir. Vakaların çoğu hastalığın başlangıcından 1-2 hafta sonra iyileşirken bazılarında alt solunum yolu enfeksiyonları izlenebilir. ${ }^{18}$ Çin'de 3 değişik seri (20, 34, 9 olguluk) olarak çocuk vakaları bildirilmiştir. İlk seride 20 çocukta düşük-orta ateş veya ateş gözlenmezken, rinit, öksürük, yorgunluk, baş ağrısı, ishal ve ağır kliniği olanlarda ise dispne, siyanoz ve iştahsızlık mevcuttu. ${ }^{19} 34$ çocuk üzerinde yapılan incelemelere göre çocuklarda başka herhangi bir hastalık yoktu. Çocukların \%65'inde yaygın solunum semptomları, \%26'sında hafif solunum semptomları gözlenirken \%9'unda semptom gözlenmedi. En yaygın klinik bulgu ise $\% 50$ 'sinde ateş ve $\% 38^{\prime}$ inde öksürük idi. ${ }^{20} 9$ süt çocuğundan oluşan seride, birinde toraks BT'de buzlu cam opasitesi izlendi. Çocukların çoğunda 1-2 hafta içinde iyileşme gözlendi. ${ }^{20}$ SARS-KoV-2 enfeksiyonlu 9 anneden süt çocuklarına SARS-KoV-2'nin vertikal geçişi olmamıştır. ${ }^{21}$ COVID-2019 enfeksiyonunun klinik tablosunun sinıflandırılması Tablo 1'de gösterilmiştir.

\begin{tabular}{|c|c|c|}
\hline \multicolumn{3}{|c|}{ Tablo 1: COVID-19 enfeksiyonu klinik tablo sınıflandırılması. ${ }^{18}$} \\
\hline 1 & $\begin{array}{l}\text { Asemptomatik enfek- } \\
\text { siyonlar veya sessiz en- } \\
\text { feksiyonlar }\end{array}$ & $\begin{array}{l}\text { SARS-KoV-2 için pozitif olan ancak klin- } \\
\text { ik semptomları veya akciğer görüntüleme } \\
\text { bulgularında anormallik gözlenmeyen } \\
\text { çocuklar }\end{array}$ \\
\hline 2 & $\begin{array}{l}\text { Akut üst solunum yolu } \\
\text { enfeksiyonu }\end{array}$ & $\begin{array}{l}\text { Sadece ateş, öksürük, faringeal ağrı, burun } \\
\text { tıkanıklığı, yorgunluk, baş ağrısı, miyalji } \\
\text { gibi semptomları olan ancak akciğer grafil- } \\
\text { erinde pnömoni belirtisi veya sepsisi olma- } \\
\text { yan çocuklar }\end{array}$ \\
\hline 3 & Hafif pnömoni & $\begin{array}{l}\text { Ateş eşliğinde veya ateş olmadan öksürük } \\
\text { gibi solunum semptomları mevcut; akciğer } \\
\text { görüntülemede pnömoni belirtisi olan an- } \\
\text { cak ağır pnömoni seviyesine ulaşmamış } \\
\text { çocuklar }\end{array}$ \\
\hline 4 & Ağır pnömoni & $\begin{array}{l}\text { Artmış solunum hızı } \geq 70 / \text { dakika }(<1 \\
\text { yaş), } \geq 50 \text { /dakika ( } \geq 1 \text { yaş) (ateş ve ağlama } \\
\text { elimine edildikten sonra); oksijen satüra- } \\
\text { syonu }<\% 92 \text {; solunum bozukluğu (inleme, } \\
\text { burun kanadı solunumu), siyanoz, aralıklı } \\
\text { apne beraberliğinde hipoksi; bilinç kaybı, } \\
\text { somnolans, koma veya konvülziyon; de- } \\
\text { hidratasyon belirtisi ile beraber iştahsızlık } \\
\text { veya besleme zorluğu }\end{array}$ \\
\hline 5 & $\begin{array}{l}\text { Kritik vakalar (yoğun } \\
\text { bakım ünitesine alın- } \\
\text { ması gereken vakalar) }\end{array}$ & $\begin{array}{l}\text { Mekanik ventilasyon gerektiren solunum } \\
\text { yetmezliği; şok; diğer organ yetmezliklerin- } \\
\text { in de eşlik ettiği komplike durumlar }\end{array}$ \\
\hline
\end{tabular}

\section{Laboratuvar bulguları}

Laboratuvar bulgularında, lökosit sayısı normal veya dü- 
şük olmakla birlikte lenfosit, nötrofil, trombosit sayısı da düşük izlenebilir. Karaciğer enzimleri ve miyohemoglobin seviyeleri bazı hastalarda yükselebilir. Çoğu hastada C-reaktif protein (CRP) ve prokalsitonin seviyesi normal seyrederken, ağır vakalarda artmış D-dimer, laktat dehidgrogenaz (LDH) düzeyleri, bozuk karaciğer fonksiyon testleri ve koagülopati görülebilir. SARS-KoV-2 varlığının tespiti için boğaz sürüntüsü, balgam, alt solunum yolu salgıları, dışkı ve kan örnekleri laboratuarda kullanılır. ${ }^{19,22-25}$ 34 çocuk vaka serisinde, hastaların \%83'ünde hemogramı normal iken sadece \%1'inde nötropeni ve lenfopeni izlenirken, vakaların \%30'unda LDH seviyesi yüksek idi. ${ }^{20}$

\section{Akciğer bulguları}

Şüpheli veya kesin vakalarda akciğer grafisi alınmalıdır. Toraks bilgisayarlı tomografisi (BT) gerekli durumlarda istenebilir. Akciğer görüntülerinde bilateral yamalı, nodüler alanlar, buzlu-cam görüntüsü ve/veya akciğerin orta veya perifer bölgesinde infiltrasyon alanları görülürken, ağır vakalarda akciğgerde konsolidasyon görülebilir. Plevral efüzyon ise sık görülmez. ${ }^{20,22-27}$

\section{COVID-19 Enfeksiyonunda Tanı}

COVID-2019 enfeksiyonunda kesin tanısı solunum yollarından alınan örneklerin reverz transkriptaz polimeraz zincir reaksiyonu (RT-PCR) ile konulur. COVID-19 enfeksiyon şüphesi hastaya yaklaşımın algoritması resim 1'de gösterilmiştir. Klinik olarak şüpheli vakalardan nazofarengeal ve/veya boğaz sürüntüsü alınır. ${ }^{28-29}$ SARS-KoV-2 enfeksiyonlarında şüpheli vakalar tanımlanırken epidemiyolojik öykü ve klinik bulgular beraber değerlendirilir. Şüpheli ve kesin vakalarda tanının nasıl konulacağı tablo 2 a ve 2 b'de gösterilmiştir.

\begin{tabular}{|l|l|l|}
\hline \multicolumn{3}{|l|}{$\begin{array}{l}\text { Tablo 2a. Epidemiyolojik öyküsünde aşağıdaki kriterlerden herhangi } \\
\text { birini ve klinik bulguların herhangi iki tanesini karşılayan vakalar } \\
\text { şüpheli vaka olarak değerlendirilir. }{ }^{18}\end{array}$} \\
\hline \multicolumn{1}{|c|}{ Epidemiyolojik öykü } & Klinik öykü \\
\hline 1 & $\begin{array}{l}\text { Semptomların başlamasından önce- } \\
\text { ki } 14 \text { gün içerisinde, salgının olduğu } \\
\text { bölge, komşu bölge veya bölgesel ak- } \\
\text { tarma alanlarına seyahat veya oturma } \\
\text { öyküsü olan olgular }\end{array}$ & $\begin{array}{l}\text { Ateş, yorgunluk, kuru } \\
\text { ökürük, bazı çocuk hast- } \\
\text { alarda düşük-seviyeli ateş } \\
\text { veya ateş yok }\end{array}$ \\
\hline 2 & $\begin{array}{l}\text { Semptomların başlamasından önce- } \\
\text { ki 14 gün içerisinde, salgının olduğu } \\
\text { bölge, komşu bölgelerine veya lokal } \\
\text { aktarma alanlarındaki ateş ve solunum } \\
\text { semptomlarına sahip hastalara temas } \\
\text { öyküsü olan çocuklar }\end{array}$ & $\begin{array}{l}\text { Akciğer görüntülüme } \\
\text { tekniklerinden elde edilen } \\
\text { bulgular }\end{array}$ \\
\hline \multirow{3}{3}{3} & $\begin{array}{l}\text { Salgınla bağlantılı veya SARS-KoV-2 } \\
\text { ile enfekte vakalarıyla yakın teması } \\
\text { olan çocuklar }\end{array}$ & $\begin{array}{l}\text { Hastalığın erken evresinde, } \\
\text { normal veya azalmış lökosit } \\
\text { değerleri ve azalmış lenfosit } \\
\text { sayısı beraberliği }\end{array}$ \\
\hline 4 & $\begin{array}{l}\text { SARS-KoV-2 enfekte annelerden } \\
\text { doğan yenidoğanlar }\end{array}$ & $\begin{array}{l}\text { Klinik bulgularında diğer } \\
\text { patojenlerin varlığının } \\
\text { saptanmaması }\end{array}$ \\
\hline
\end{tabular}

\begin{tabular}{|l|l|}
\hline \multicolumn{2}{|l|}{$\begin{array}{l}\text { Tablo } 2 \text { b. Aşağıdaki kriterlerden herhangi birini karşılayan şüpheli } \\
\text { vakalar kesin vaka olarak kabul edilir. }{ }^{18}\end{array}$} \\
\hline 1 & $\begin{array}{l}\text { RT-PCR tekniği ile bakılan solunum yolu veya kan örneklerinde } \\
\text { SARS-KoV-2 nükleik asidinin pozitif bulunması }\end{array}$ \\
\hline 2 & $\begin{array}{l}\text { Solunum yolu veya kan örneklerinde çıan viral genomun SARS- } \\
\text { KoV-2' nin genetik sekansina yüksek seviyede benzerlik göstermesi }\end{array}$ \\
\hline
\end{tabular}

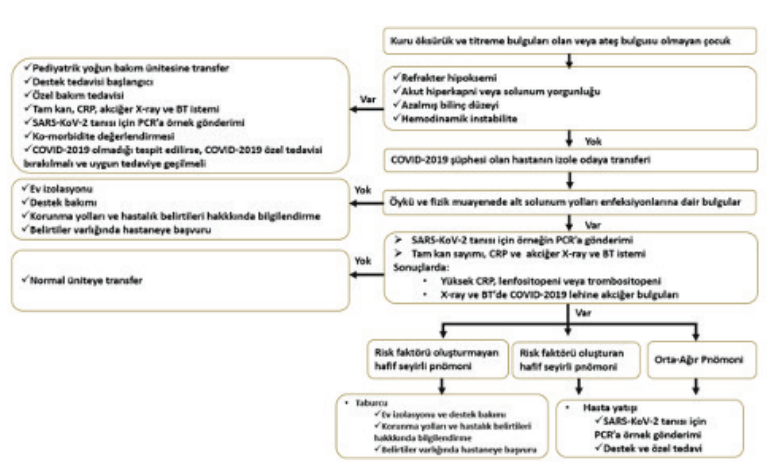

Resim 1: COVID-19 şüphelenilen çocuk hastaya yaklaşım algoritmasi. ${ }^{42}$

\section{Kritik Vakalarda Erken Tanımlama}

SARS-KoV-2 enfekte vakalar ile temas öyküsü olan ya da pnömoniye neden olabilecek konjenital kalp hastalığı, pulmoner hipoplazi, solunum yolu anomalileri gibi durumları olan veya immün yetmezlik veya immün sistemi baskılanmış (uzun süre immünsüpresif ilaç kullanımı) çocukların aşağıdaki durumlardan herhangi birine uyması durumunda vaka ciddi/kritik olarak değerlendirilir: ${ }^{6,10,18,30}$ 
1. Dispne: 2-12 aylıklarda solunum hızı $>50 /$ dakika; $1-5$ yıl yaştakilerde solunum hızı >40 /dakika; 5 yaşından büyüklerde solunum hızı >30/dakika (ateş ve ağlama elimine edildikten sonra)

2. 3-5 gün boyunca devam eden persistan yüksek ateş

3. Zayıf zihinsel reaksiyonlar, letarji, bilinç kaybı, diğer bilinç durumları

4. Anormal derecede artmış enzimatik değerler (örneğin miyokardial enzimler, karaciğer enzimleri, laktat dehidrogenaz -LDH)

5. Açılanamayan metabolik asidoz

6. Akciğer görüntüleme tekniklerinde bilateral veya çoklu-lob infiltrasyonu, plevral efüzyon veya kısa zaman diliminde durumda hızlı ilerleme

7. Üç aylıktan daha küçük süt çocukları

8. Ekstrapulmoner komplikasyonlar

9. Diğer virüs ve/veya bakterilerle ko-enfeksiyon

\section{Tedavi}

Klinik durumları göz önünde bulundurularak, şüpheli hastalar evde tek kişilik bir odada doktor tavsiyesine uyularak izole edilmelidir. Kritik vakalar mümkün olan en kısa sürede yoğun bakım ünitelerine götürülmelidir.

\section{Genel tedavi}

Çocuklarda yatak istirahati, yeterli kalori ve su alımı ile birlikte gerekli ise oksijen desteği verilmelidir. Temel amaç respiratuar distres sendromu (ARDS), organ yetmezliği ve sekonder nozokomiyal enfeksiyonların önüne geçmektir. Bakteriyel enfeksiyonlardan şüphelenilmesi durumunda geniş-spektrumlu antibiyotikler reçete edilmelidir. Yüksek ateş gibi semptomlara sahip hastalar sürekli kontrol edilmelidir. Eğer belirgin huzursuzlukla beraber ateşi $38.5^{\circ} \mathrm{C}^{\prime} y i$ geçerse, fiziksel soğutma (1lık uygulama) veya antipiretik ilaç tedavisi başlanılmalıdır. İbuprofen ve nonsteroid anti-enflamatuar ilaçların SARS-KoV-2 enfeksiyonu esnasında kullanımından kaçınılması WHO tarafından önerildiğinden oral yoldan $5-10 \mathrm{mg} / \mathrm{kg}$ parasetamol verilebilir. Konvülziyon ve nöbet durumlarında çocuk hasta sakin tutulmalı ve hemen anti-konvülzan verilmelidir. Hipoksi durumunda, nazal kateter ve oksijen maskesi dahil etkili bir şekilde oksijen tedavisi acilen verilmelidir. Nazal yüksek-akım oksijen tedavisi ve non-invazif veya invazif mekanik ventilasyon gerekli görüldügünde uygulanılmalıdır.

\section{Antiviral tedavi}

İnterferon- $\alpha$ enfeksiyonun erken dönemlerinde viral yükü azaltabilir ve semptomları hafifleterek hastalığın süresini k1saltabilir. $22,31-33$

1. İnterferon- $\alpha$ nebulizasyonu: $200.000-400.000 \mathrm{IU} / \mathrm{kg}$ interferon- $\alpha$ veya $2 \mathrm{ml}$ steril suda $2-4 \mu \mathrm{g} / \mathrm{kg}$ interferon- $\alpha$, 5-7 gün boyunca günde iki kere nebülizasyon

2. İnterferon- $\alpha 2 \beta$ sprey: SARS-KoV-2'nin enfeksiyonu olduğundan şüphelenilen hastayla yakın temasta olan veya sadece üst solunum yolu enfeksiyonun erken evresinde bulunanların olduğu yüksek-risk popülasyonunda uygulanır. 5-7 gün boyunca, 1-2 saatte bir, nazal kavitenin her iki tarafına 1-2 sprey, orofarinkse 8-10 sprey, her kullanımda doz başına 8.000 IU interferon- $\alpha 2 \beta, 8$-10 sprey/gün olarak uygulanır.

Arbidol, sadece Rusya ve Çin'de üretilen yetişkin COVID-19 hastalarında kullanılır, ancak etkinliği ve güvenilirliği belirsizdir. ${ }^{34}$

Oseltamivir ve diğer anti-influenza ajanları, diğer influenza virüsleri ile ko-enfekte olan hastalarda kullanılabilir. ${ }^{35}$ Lopinavir/ritonavir COVID-19'un yetişkin pnömonili hastalarının tedavisinde kullanılmış ancak etkinliği ve güvenliği belirsizdir. ${ }^{22,36,37}$

Klorokin antimalaryal ajan olup otofaji ve Toll-like reseptörleri (TLR) inhibe eder. İn vitro çalışmalarda SARSKoV-2'yi inhibe eden FDA onaylı bir ilaçtır. Hidroksiklorokin ise hem antimalarya hem de anti-inflamatuvar ajan olup TLR-7/-9 sinyal yolağını inhibe eder. Hidroksiklorokin, klorokin gibi, SARS-KoV'yi inhibe eden FDA onaylı anti-viral bir ilaçtır. Klorokin antiviral aktivitesinin, hidroksiklorokinine göre daha yüksek olduğu düşünülmektedir. $^{38-40}$ QT uzaması yapan ilaçlar (örn. Azitromisin, mok- 
sifloksasin vb) ile birlikte kullanılırken dikkat edilmelidir. Remdesivir, in vitro ve hayvan çalışmalarında SARSKoV-2, SARS ve MERS'e e karşı aktivite gösterdiği bildirilen bir ilaçtır. RNA virüslerinin RNA polimeraz nükleotid analog inhibitörü olarak davranır. COVID-2019'daki etkinliği ve klinik etkileri üzerine çalışmalar devam etmektedir. $^{41,42}$

Favipravir, klinik etkinliğini virus RNA polimeraz aktivitesini durdurarak gösterir. ${ }^{41,42}$

\section{Antibiyotik tedavisi}

Özellikle geniş-spektrumlu antibiyotik kullanımı ile beraber orantısız antibiyotik kullanımından kaçınılmalıdır. Bakteriyel ve fungal enfeksiyonla ko-enfekte olan çocuk hastaların durumundaki değişiklikler yakından takip edilmeli; örneklerden patojen analizi yapılmalı veya antibiyotik veya antifungal ilaç kullanımı gerektikçe ve makul düzeyde olmalıdır. ${ }^{22,43}$

\section{Diğer Ajanlar}

Glukokortikoidler sistemik inflamatuvar yanıtın şiddetine, ARDS'li ve ARDS'siz hastalarda dispnenin derecesine ve akciğer grafi sonuçlarındaki ilerleme durumuna göre verilmelidir. Glukokortikoidler, 3-5 günlük kısa süreli bir zaman diliminde kullanılabilir. Metilprednizolon 1-2 mg/ kg/gün dozunu geçmemelidir. İntravenöz immunoglobulin tedavisi, ağır vakalarda kullanılabilir ancak etkinliği belirsizdir. $^{22,43}$

\section{A ğır ve kritik hastaların tedavisi}

Non-invazif mekanik ventilasyonda 2 saat boyunca klinik durumda iyileşme göstermeyen veya artan solunum yolu sekresyonu, şiddetli öksürük veya stabil olmayan hemodinamiği ile beraber non-invazif ventilasyonu kaldıramayan çocuklarda hemen invazif mekanik ventilasyona geçilmesi gerekir. Ventilatöre bağlı akciğer hasarını minimize etmek için invazif mekanik ventilasyonun düşük tidal hacimde ayarlanması gerekir. Gerekli görülürse, yüz üstü pozisyonda ventilasyon, akciğer recruitment manevraları veya ekstrakorporal membran oksijenasyonu (ECMO) uygulanmalıdır. Hastanın tam sıvı resüssitasyon mantığına dayanarak dolaşımı iyileştirilmeli, vazoaktif ilaç kullanılmalı ve hemodinamik izleme alınmalıdır.

\section{Yayılımını Önleme}

SARS-KoV-2 ile enfekte hastalar enfeksiyonun ana kaynağıdır. SARS-KoV-2 ile enfekte çocuklar evde izole edilmeli veya sağlık personelinin tavsiyeleri doğrultusunda hastalığın şiddetine göre özel bir hastane odasında tutulmalıdır. İzole çocuklar tek bir odada tutulmalı ve evde yaşayanlarla teması minimize edilmelidir. Çocuklar tarafından kullanılan eşyalar dezenfekte edilmeli, oda temiz tutulmalı ve odanın havalandırması yapılmalıdır. Hastanın bakımı yapılırken maske takılmalı ve sonrasında atılmalıdır. ${ }^{44}$

Yayılma yollarını önlemek için;

1. Damlacık veya temas yolu ile bulaşın önlenmesi: Öksürürken veya hapşırırken peçete veya havlu ile ağız ve burun kapatılmalıdır. Eller sık yıkanmalı veya çocuklara 7 aşamalı el yıkama tekniğini öğretilmelidir. Öksürürken ve hapşırırken burnunuzu ve ağzınızı dirseğinizle kapattıktan sonra, yemekten önce veya tuvaletten sonra, toplu alanlardan geldikten sonra ağı, burun ve gözlere dokunulmadan eller iyice y1kanılmalıdır. Oyuncaklar $56^{\circ} \mathrm{C}$ 'de 30 dakika 1sitılmal1, alkol veya klorinli dezenfektanlarla ve ultraviyole 1şınlarla düzenli olarak dezenfekte edilmelidir.

2. Enfeksiyona maruziyeti minimize etme: epidemik alanlarda toplu taşımadan uzak durulmalı, toplu yerlere veya havalanması zayıf bölgelere giderken maske giyilmeli, yabani hayvanlara dokunulmamalı ve bu hayvanlar yenilmemeli ve bu tür hayvan satım yerlerine gidilmemelidir.

3. Çocuk sağlığının takibi: Enfekte hastalarla yakın temas öyküsü olan çocukların vücut ateşi ve klinik bulguları rutin olarak takip edilmelidir. Şüpheli durumların varlığında, çocuklar referans hastaneye götürülmeli ve takip edilmelidir. Enfekte annelerden doğan bebeklere SARS-KoV-2 testi yapılmalı ve kli- 
nik durumlarına göre evde tek bir odada izole edil-

melidir.

\section{Bağışıklık Sistemini Destekleme}

İmmun sistemi güçlendirmek için dengeli beslenme, ağız sağlığı ve bakımı, yeterli egzersiz, aşırı yorgunluktan kaçınma gereklidir. Bağışıklığı güçlendirme, enfeksiyonu engelleme ve duygusal ve zihinsel sağlığı korumada en etkili yöntemdir. Aşı, viral enfeksiyonları önlemede en etkili aktif immünizasyon yoludur. Çin'de ve diğer bazı gelişmiş ülkelerde anti-viral aşı üzerine çalışmalar halen devam etmektedir. Ülkemiz ve diğer ülkelerde enfeksiyonu geçirenlerin plazmasından elde edilen antikorların tanısı kesinleşen ve/veya şüpheli olgulara verilimi (pasif immünizasyon), kısmi bir profilaksi veya tedavi yöntemi olarak kullanılmaya çalışılmaktadır.

\section{SONUÇ}

SARS-KoV-2'nin tüm yaş gruplarını enfekte edebildiği unutulmamalıdır. Bireyler virüsten korunma yöntemlerine uymalıdır. Güncel verilere göre kesin tanı RT-PCR tekniği ile konulmakta olup tedavi ajanları üzerine çalışmalar devam etmektedir. Sağlık çalışanlarının sıklıkla değişen güncel bilgilere ulaşmak için Sağlık Bakanlığının "https:// covid19.saglik.gov.tr/" adresinden yayınlanan rehberi takip etmelerinde fayda vardır. 


\section{Kaynaklar}

1. Lu Q, Shi Y. Coronavirus disease (COVID-19) and neonate: what the neonatologist need to know. J Med Virol 2020; 1-4.

2. Saif LJ. Animal coronaviruses: what can they teach us about the severe acute respiratory syndrome? Rev Sci Tech. 2004;23:643-660.

3. Cabeça TK, Granato C, Bellei N, et al. Epidemiological and clinical features of human coronavirus infections among different subsets of patients. Influenza Other Respir Viruses. 2013;7:1040-1047

4. Shi Z, Hu Z. A review of studies on animal reservoirs of the SARS coronavirus. Virus Res 2008; 133: 74-87.

5. Huynh J, Li S, Yount B, et al. Evidence supporting a zoonotic origin of human coronavirus strain NL63. J Virol. 2012;86:12816-12825.

6. Ovalı F. Yenidoğanlarda COVID-19 Enfeksiyonları. Anadolu Klin 2020;5(1), pp.23-35.

7. Chan JF, Yuan S, Kok KH, et al. A familial cluster of pneumonia associated with the 2019 novel coronavirus indicating person to person transmission: a study of a family cluster. Lancet 2020; 395: 514-523.

8. World Health Organization. Coronavirus disease 2019 (COVID-19) Situation Report - 32. 2020. Available at:https://www.who.int/docs/defaultsource/coronaviruse/situation-reports/20200221-sitrep-32-covid-19. pdf?sfvrsn=4802d089_2. Accessed March 2, 2020

9. World Health Organization. Novel coronavirus situation report -2. January 22, 2020. https://www.who.int/docs/default-source/coronaviruse/situation-reports/20200122-sitrep-2-2019-ncov. pdf (Accessed on January 23, 2020).

10. McIntosh K, Coronavirus Disease 2019 (COVID-19), UpToDate, retrieved from "https:// www.uptodate.com/contents/coronavirus-disease-2019-covid-19. pdf (Accessed on March 27, 2020).

11. Dong Y, Mo X, Hu Y, et al. Epidemiological characteristics of 2143 pediatric patients with 2019 coronavirus disease in China. Pediatrics 2020; pii: e20200702

12. Chen H, Guo J, Wang C, et al. Clinical characteristics and intrauterine vertical transmission potential of COVID-19 infection in nine pregnant women: a retrospective review of medical records. Lancet 2020; 395:809.

13. Zhu H, Wang L, Fang C, et al. Clinical analysis of 10 neonates born to mothers with 2019nCoV pneumonia. Transl Pediatr 2020; 9:51.

14. American College of Obstetricians and Gynecologists. Practive Advisory: Novel Coronavirus 2019 (COVID-2019).https://www.acog.org/Clinical-Guidance-and-Publications/Practice-Advisories/Practice-Advisory-Novel-Coronavirus2019 (Accessed on February 26, 2020).

15. Zeng H, Xu C, Fan J et al. Antibodies in Infants Born to Mothers With COVID-19 Pneumonia. JAMA.2020;EPUB:E1-E2

16. The Society of Pediatrics of Hubei Medical Association, The Society of Pediatrics of Wuhan Medical Association, Hubei Pediatric Medical Quality Control Center. Suggestions on the diagnosis and treatment of novel coronavirus infection in children in Hubei province (trial version 1). CJCP. 2020;22:96-9

17. Chan JF, Yuan S, Kok KH, et al. A familial cluster of pneumonia associated with the 2019 novel coronavirus indicating person to-person transmission: a study of a family cluster. Lancet. 2020;395(10223):514-523.

18. Shen K, Yang Y, Wang T, et al. China National Clinical Research Center for Respiratory Diseases; National Center for Children's Health, Beijing, China; Group of Respirology, Chinese Pediatric Society, Chinese Medical Association; Chinese Medical Doctor Association Committee on Respirology Pediatrics; China Medicine Education Association Committee on Pediatrics; Chinese Research Hospital Association Committee on Pediatrics; Chinese Non-government Medical Institutions Association Committee on Pediatrics; China Association of Traditional Chinese Medicine, Committee on Children's Health and Medicine Research; China News of Drug Information Association, Committee on Children's Safety Medication; Global Pediatric Pulmonology Alliance. Diagnosis, treatment, and prevention of 2019 novel coronavirus infection in children: experts' consensus statement. World J Pediatr. $2020 \mathrm{Feb} 7$.

19. Chen $Z M, F u J F, S h u$ Q, et al. Diagnosis and treatment recommendations for pediatric respiratory infection caused by the 2019 novel coronavirus. World J Pediatr. 2020.

20. Wang XF, Yuan J, Zheng YJ, et al. Clinical and epidemiological characteristics of 34 children with 2019 novel coronavirus infection in Shenzhen. Zhonghua Er Ke Za Zhi. 2020;58:E008.

21. Wei M, Yuan J, Liu Y, et al. Novel coronavirus infection in hospitalized infants under 1 year of age in China. JAMA. 2020.
22. National Health Commission of People's Republic of China. Diagnosis and treatment of pneumonia caused by novel coronavirus (trial version 4). https ://www.nhc.gov.cn/ xcs/zheng cwj/202001/42945 63ed3 $5643209 b 31$ 739bd 0785e 67/files /7a930 91112 67475a99d4 30696 2c8bf 78.pdf. Access 28 Jan 2020.

23. Hon KL, Leung CW, Cheng WT, et al. Clinical presentations and outcome of severe acute respiratory syndrome in children. Lancet. 2003;361:1701-1703.

24. Chiu WK, Cheung PC, $\mathrm{Ng} K \mathrm{KL}$, et al. Severe acute respiratory syndrome in children: experience in a regional hospital in Hong Kong. Pediatr Crit Care Med. 2003;4:279-283.

25. Bitnun A, Allen U, Heurter $H$, et al. Children hospitalized with severe acute respiratory syndrome-related illness in Toronto. Pediatrics. 2003;112:e261.

26. Feng K, Yun YX, Wang XF, et al. Analysis of CT features of 15 children with 2019 novel coronavirus infection. Zhonghua Er Ke Za Zhi. 2020;58:E007

27. Babyn PS, Chu WC, Tsou IY, et al. Severe acute respiratory syndrome (SARS): chest radiographic features in children. Pediatr Radiol. 2004;34:47-58.

28. Gaunt ER, Hardie A, Claas EC, et al. Epidemiology and clinical presentations of the four human coronaviruses 229E, HKU1, NL63, and OC43 detected over 3 years using a novel multiplex real-time PCR method. J Clin Microbiol. 2010;48:2940-2947.

29. Vabret A, Mouthon F, Mourez T, et al. Direct diagnosis of human respiratory coronaviruses 229E and OC43 by the polymerase chain reaction. J Virol Methods. 2001;97:59-66.

30. Al Johani S, Hajeer AH. MERS-CoV diagnosis: an update. I Infect Public Health. 2016;9:216-219

31. Wang BX, Fish EN. Global virus outbreaks: interferons as 1st responders. Semin Immunol. 2019;43:101300.

32. Al-Tawfiq JA, Momattin H, Dib J, et al. Ribavirin and interferon therapy in patients infected with the Middle East respiratory syndrome coronavirus: an observational study. Int I Infect Dis. 2014;20:42-6.

33. Wang $H Q$, Ma LL, Jiang JD, et al. Recombinant human interferon alpha $2 b$ broad-spectrum anti-respiratory viruses pharmacodynamics study in vitro. Acta Pharmaceu Sin. 2014;49:1547-53

34. Ji XG, Zhao YH, Zhang M, et al. The Experimental Study of the Anti-SARS-CoV Effect of Arbidole. Pharm J Chin PLA. 2004;20:274-6.

35. National Health Commission of People's Republic of China. Influenza diagnosis and treatment protocol (revised edition 2019). https://wenku .baidu .com/view/00fod 41 d20 79168 884868762 c aaedd3383c 4b57f.html. Access 30 Nov 2019.

36. Chu CM. Role of lopinavir/ritonavir in the treatment of SARS:initial virological and clinical findings. Thorax. 2004;59:252-6.

37. AbbVie Deutschland GmbH \& Co.KG. Lopinar veletonavir tablet specification. https :// www.jiank e.com/produ ct/79823.html. Access 7 July 2017.

38. Savarino A, Di Trani L, Donatelli I, et al. New insights into the antiviral effects of chloroquine. Lancet Infect Dis. 2006;6:67-69.

39. Vincent MJ, Bergeron E, Benjannet S, et al. Chloroquine is a potent inhibitor of SARS coronavirus infection and spread. Virol J. 2005;2:69.

40. Wang $M$, Cao $R$, Zhang $L$, et al. Remdesivir and chloroquine effectively inhibit the recently emerged novel coronavirus (2019- $n$ CoV) in vitro. Cell Res. 2020:269-271.

41. Sheahan TP, Sims AC, Leist SR, et al. Comparative therapeutic efficacy of remdesivir and combination lopinavir, ritonavir, and interferon beta against MERS-CoV. Nature Communications 2020; 11:222.

42. Karimi A, Tabatabaei SR, Rajabnejad M, et al. An Algorithmic Approach to Diagnosis and Treatment of Coronavirus Disease 2019 (COVID-19) in Children: Iranian Expert's Consensus Statement. Arch Pediatr Infect Dis 8(2): e102400.

43. National Health Commission of People's Republic of China. Code for the diagnosis and treatment of community-acquired pneumonia in children (2019 edition). https ://www.nhc. gov.cn/yzygj/s7653/20190 2/bfa75 8ad6a dd48a 599bc $74 b 58$ 8a6e8 9a.shtml. Access 11 Feb 2019.

44. Zimmermann P, Curtis N. Coronavirus Infections in Children Including COVID-19: An Overview of the Epidemiology, Clinical Features, Diagnosis, Treatment and Prevention Options in Children. The Pediatric Infectious Disease Journal, 2020; Online First. 